\title{
Associations of ostracods in shallow lakes in the northeast of La Pampa province (Argentina)
}

\author{
Romina KIHN ${ }^{1,2}$, Santiago ECHANIZ1 ${ }^{1}$, Alicia VIGNATTI ${ }^{1}$, Gabriela CABRERA $^{1}$ \& César STELLA ${ }^{3}$ \\ ${ }^{1}$ Facultad de Ciencias Exactas y Naturales-Universidad Nacional de La Pampa; e-mail: santiagoechaniz@ \\ exactas.unlpam.edu.ar. ${ }^{2}$ CONICET. ${ }^{3}$ Museo Provincial de Ciencias Naturales
}

\begin{abstract}
Shallow lakes are common in the center of Argentina. Although many characteristics of its biota are known, information on the distribution and ecology of ostracods is scarce despite their importance as biological indicators and in actuopaleontology. The objective of this study was to determine the taxonomic composition, the density of ostracods, and their relationships with environmental parameters in lakes in the northeast of La Pampa. Five aquatic ecosystems were studied from September 2016 to March 2017. Samples of superficial sediments were collected, and conductivity, temperature, and transparency were measured in situ. Water samples were collected to determine salinity, $\mathrm{pH}$, and ionic composition. The lakes differed in salinity, ionic composition, and transparency. Ten taxa were registered, some previously found in the province of Buenos Aires (Heterocypris similis, Heterocypris incongruens, Cypridopsis vidua, and Chlamydotheca incisa), the Llancanelo basin (H. incongruens and C. vidua), and North Patagonia lakes (C. incisa, C. vidua, Potamocypris unicaudata, H. incongruens, and Amphicypris argentiniensis). The influence of salinity was verified because some species (A. argentinensis, Limnocythere rionegroensis, and Limnocythere titicaca) were found only in the most saline lake. The existence in La Pampa of three different ecoregions (Pampean Plains, Espinal, and Patagonian Steppe) and the presence of ostracods in the studied lakes of northwestern Argentina (L. titicaca), the Buenos Aires province plain $(H$. similis, H. incongruens), and Patagonia (L. rionegroensis) allowed for affirming that the lakes of La Pampa are in a transition zone among different ostracods faunas.
\end{abstract}

Keywords: Non-marine ostracods, living ostracods, Limnocythere rionegroensis, Limnocythere titicaca.

Resumen: Asociaciones de ostrácodos de lagos someros del noreste de la provincia de La Pampa (Argentina). Los lagos someros son frecuentes en La Pampa. Aunque muchas características de su biota son conocidas, la información sobre la distribución y ecología de los ostrácodos es escasa, a pesar de su importancia como indicadores biológicos y en actuopaleontología. El objetivo de este estudio es conocer la composición taxonómica, la densidad de ostrácodos y sus relaciones con parámetros ambientales en lagos del noreste de La Pampa. Se estudiaron cinco lagos desde septiembre de 2016 hasta marzo de 2017. Se tomaron muestras de sedimentos superficiales e in situ se midieron: conductividad, temperatura y transparencia y se tomaron muestras para determinar salinidad, $\mathrm{pH}$ y composición iónica. Los lagos difirieron en su salinidad, composición iónica y transparencia. Se registraron diez taxa, algunos hallados previamente en la provincia de Buenos Aires (Heterocypris similis, Heterocypris incongruens, Cypridopsis vidua y Chlamydotheca incisa), la cuenca de Llancanelo (H. incongruens y C. vidua) y lagos del norte de Patagonia (C. incisa, C. vidua, Potamocypris unicaudata, H. incongruens y Amphicypris argentiniensis). Se comprobó la influencia de la salinidad ya que algunas especies (A. argentinensis, Limnocythere rionegroensis y Limnocythere titicaca) se encontraron sólo en el lago más salino. La existencia en La Pampa de tres ecorregiones diferentes (Llanura Pampeana, Espinal y Estepa Patagónica) y la presencia en los lagos estudiados de ostrácodos del noroeste argentino (L. titicaca), de la llanura bonaerense (H. similis, $H$. incongruens) y otras de Patagonia (L. rionegroensis), permitiría afirmar que los lagos de La Pampa están en una zona de transición entre faunas diferentes.

Palabras clave: Ostrácodos no marinos, ostrácodos vivientes, Limnocythere rionegroensis, Limnocythere titicaca.

\section{INTRODUCTION}

Most aquatic ecosystems of La Pampa Province are shallow lakes. Additionally, most of these ecosystems are saline lakes (TDS $>3 \mathrm{~g} / \mathrm{L}$
(Hammer, 1986), in which $\mathrm{Cl}^{-}$and $\mathrm{Na}^{+}$are the dominant ions. However, in the province there are some subsaline lakes, usually located in dune areas with $\mathrm{HCO}_{3}^{-}$and $\mathrm{Na}^{+}$or $\mathrm{Ca}^{2+}$ dominance (Echaniz \& Vignatti, 2019). 
Many physical-chemical and biological characteristics of the lakes in La Pampa Province have been studied, but of the latter, the most attention has been given to phytoplanktonic and zooplanktonic communities (Echaniz \& Vignatti, 2017; 2019; Echaniz et al., 2006; 2012; Vignatti et al., 2007).

As the benthic community can be a useful tool to evaluate the characteristics of lakes, the study of ostracods has taxonomic, biogeographic, and ecological importance. In addition, determining the response of its community to different environmental parameters has attracted considerable interest because ostracods are good indicator organisms (Ruiz et al., 2013; Echeverría Galindo et al., 2019). Furthermore, knowledge about living ostracods can be used in actuopaleontology studies to examine the evolution of lakes in the recent past (Laprida et al., 2006; D'Ambrosio et $a l ., 2017)$, especially considering the current scenarios of climate change (Barros et al., 2014).

Ostracods are small crustaceans with a chitin-calcareous bivalve shell, which are able to inhabit a wide range of aquatic ecosystems. Ostracods are free-living and widely distributed in both marine and non-marine environments. Among the latter, ostracods will inhabit permanent or temporary environments with fresh or saline water, from small ponds to large lakes or humid, semi-terrestrial environments such as the soils of tropical forests (Shornikov, 1980; Pinto et al., 2005; Perçin-Paçal, 2011). Ostracods are usually benthic (Pieri et al., 2009), and also could be associated with algae or aquatic vegetation (D'Ambrosio et al., 2017). In other words, these organisms may crawl on the bottom of a waterbody, burrow in sediments, or swim amongst macrophytes. There are no truly planktonic nonmarine ostracod species, but the early juvenile stages of some species are free-swimming and act as dispersal stages (Martens \& Horne, 2016).

In continental waters, ostracod species distribution is controlled primarily by salinity or conductivity (Martínez-García et al., 2015; Cárdenas et al., 2015; D’Ambrosio et al., 2017), temperature, oxygen availability and substrate type, drought, water chemistry, acidification, turbidity, eutrophication, or the amount of organic matter (Pérez et al., 2010; Van der Meeren et al., 2010; Perçin-Paçal, 2011). In addition, the same environmental parameters influence the structures of ostracod assemblages (Ruiz et al., 2013; Coviaga et al., 2015). Further, these microcrustaceans show high sensitivity to pesticides, herbicides, heavy metal pollution, and oil inputs, so they may be included within the most promising sentinel groups in freshwater areas (Ruiz et al., 2013). The study of the ecology of non-marine ostracods is of value to water quality monitoring and management because different species respond in different ways to organic pollution and thus have potential as indicators of habitat disturbance (Mezquita et al., 1999).

In the Neotropical bioregion, studies on the ecology and biogeography of non-marine ostracods are relatively scarce, despite the importance of this field of study in paleoclimate and paleoecological reconstructions (D'Ambrosio et al., 2017). In Argentina, there have been some studies on ostracod assemblages in Patagonian lakes (Schwalb et al., 2002; Cusminsky et al., 2005; 2011; Ballent \& Díaz, 2012; Ramón Mercau et al., 2012; Coviaga et al., 2015; 2018), the Altiplano of Northern Argentina (Laprida, 2006; Díaz \& Lopretto, 2011; Palacios-Fest et al., 2016; D'Ambrosio et al., 2020), the Pampean region (César et al., 2001; Laprida, 2006; Liberto et al., 2012; Ramón Mercau et al., 2012), and the Payunia region, in the south of Mendoza province (D’Ambrosio et al., 2017).

In La Pampa Province, located in the center of Argentina, studies on the taxonomy, distribution, and ecology of ostracods are very scarce, existing only those of Khin \& Pall (2013); Kihn et al. (2017) and Coviaga et al. (2018). Therefore, the objective of the present study is to determine the taxonomic composition, the density of ostracods, and their relationships with the main limnological parameters in shallow and relatively small lakes with different characteristics in the northeast of La Pampa province.

\section{MATERIALS AND METHODS}

\section{Study area}

Ostracods from the following five aquatic ecosystems located in northeastern La Pampa were studied: La Tradicion East (LTE) $\left(35^{\circ} 17^{\prime}\right.$ $\left.57^{\prime \prime} \mathrm{S} ; 63^{\circ} 37^{\prime} 36^{\prime \prime} \mathrm{W}\right)$, La Tradicion West (LTW) ( $35^{\circ} 17^{\prime} 43^{\prime \prime}$ S; 63 37' 52" W), Dos Molinos (DMo) (35 22' 20" S; 63 36' 19" W), Ustarroz (Ust) $\left(35^{\circ} 22^{\prime} 30^{\prime \prime} \mathrm{S} ; 63^{\circ} 34^{\prime} 45^{\prime \prime} \mathrm{W}\right)$ and El Bellaco (EBe) (35 27' 08" S; 63 36' 18" W) (Fig. 1). All are located at $120-121 \mathrm{~m}$ above mean sea level. LTE and LTW are located very close to each other but are not superficially connected. LTE and DMo are relatively small, less than 1 ha, have variable vegetation cover (especially Schoenoplectus californicus (C.A. Mey.) Soják), whereas the other ecosystems range from 22 ha $(\mathrm{EBe})$ to $200 \mathrm{ha}$ (Ust) and lack aquatic vegetation. 


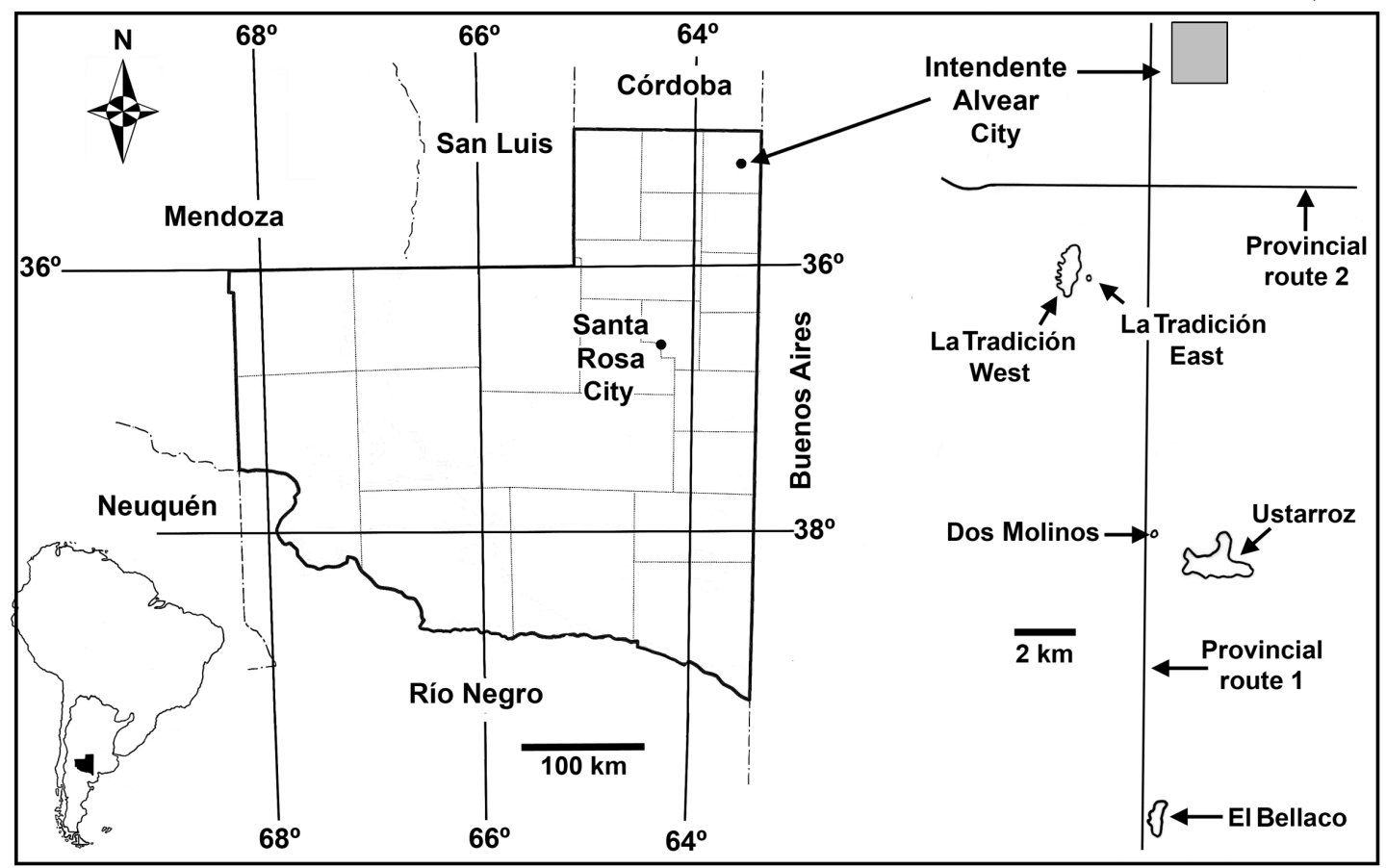

Fig. 1. Geographical locations of the five aquatic ecosystems studied in La Pampa province.

All of these ecosystems are located at the western end of the Pampa ecoregion, in the Pampa Arenosa Anegable Complex, a region characterized by a humid temperate climate with an average annual rainfall close to $800 \mathrm{~mm}$ and an average temperature of $15^{\circ} \mathrm{C}$ (Morello et al., 2012). This region is also characterized by dune fields that hinder drainage and by a predominance of livestock and agriculture; therefore, only small patches of natural vegetation (psammophyllic grasslands) remain in this area (Morello et al., 2012).

\section{Field and laboratory work}

Samples were obtained in September and November of 2016 and January and March of 2017. A total a 60 sediment samples were collected. From each lake, three samples of the two superficial centimeters of sediment were collected with a metallic ring ( $10 \mathrm{~cm}$ in diameter) in transects from the shore to the interior of the lake, with a distance of $20 \mathrm{~cm}$ between samples. The maximum depths of LTE and DMo were very close to the coast, so the samples from these lakes were collected along a line parallel to the coastline, with a distance of $2 \mathrm{~m}$ between samples.

In situ conductivity and temperature were measured with an Oakton DO6+ multiparameter probe, dissolved oxygen concentration with a Lutron OD 5510 oximeter, and water trans- parency was determined with a $20 \mathrm{~cm}$ diameter Secchi disk. On all occasions, water samples were collected to determine salinity (as solid residue by drying at $104^{\circ} \mathrm{C}$ ) and $\mathrm{pH}$ (with a Corning PS $15 \mathrm{pH}$ meter). In January 2017, one water sample was collected from each lake to determine the ionic composition according to standardized routines: $\mathrm{Na}^{+}$(selective ion electrode); $\mathrm{K}^{+}$(determination of the intensity of the turbidity by the combination of potassium with sodium tetraphenylborate); $\mathrm{Ca}^{2+}$ (EDTA digital titulometric method or spectrophotometric method for very low calcium levels); $\mathrm{Mg}^{2+}$ (digital titrometric method or spectrophotometric method for very low magnesium levels); $\mathrm{Cl}^{-}$(argentometric method - digital titration with silver nitrate solution in the presence of potassium chromate - or the spectrophotometric method for very low concentrations); $\mathrm{SO}_{4}^{2-}$ (spectrophotometric determination of the intensity of the turbidity formed during the reaction of the sulfate with barium); and $\mathrm{HCO}_{3}^{-}$and $\mathrm{CO}_{3}{ }^{2-}$ (alkalinity method of phenolphthalein and digital titration) (APHA, 1992).

Dry sediment was processed and disaggregated using tap water. Then, samples were washed through a $63 \mathrm{~mm}$ mesh sieve and dried at room temperature. From the residue, $25 \mathrm{~g}$ of material was extracted and entire specimens were picked out and studied under a binocular micros- 
cope. The adult and juvenile specimens from all the samples were counted, and its density was expressed as individuals/100 $\mathrm{g}$ of sediment (indiv./100 g sed.).

Systematic determinations were based mainly on studies by Moore (1961), Bertels \& Martínez (1990), Cusminsky \& Whatley (1996), Cusminsky et al. (2005), Ferrero (2006), Laprida (2006), Meisch (2000), and Karanovic (2012). Only live specimens were considered and to differentiate live specimens from dead ones at the time of sampling, the presence of soft parts and appendages was observed.

To study differences between the environmental variables of the lakes and ostracod population parameters, a non-parametric KruskalWallis test was performed (Sokal \& Rohlf, 1995). To group the lakes based on their limnological and chemical characteristics, a single linkage and Euclidean distance cluster analysis was performed. For this analysis, only conductivity (and not salinity) was used, given the strong correlation between these two variables.

To analyze the relationship between the abundances of the different taxa and their frequencies of occurrence, an Olmstead-Tukey non-parametric test with graphs of quadrants (Sokal \& Rohlf, 1995) was applied. In this test, the density of each species (indiv./100 g sed.) was plotted on the ordinates versus the frequency of occurrence of each species (as percentages) in the abscissa. This allowed for the identification of four categories: frequent and abundant species (dominant species, quadrant I); abundant and infrequent species (occasional species, quadrant II); infrequent and scarce species (rare species, quadrant III); and frequent but scarce species (common species, quadrant IV; D'Ambrosio et al., 2016).

To determine the association between ostracods species in the lakes, a Bray-Curtis pairedgroup cluster analysis was performed.

A canonical correspondence analysis (CCA) was performed to investigate the relationship between the ostracod communities and the environmental variables because this test was created to understand how various taxa respond simultaneously to external factors (Ter Braak $\&$ Verdonshot, 1995). The densities of the different taxa were used as a biological variable, and the environmental variables were: lake depth, conductivity, temperature, oxygen, transparency, and $\mathrm{pH}$. Only conductivity (not salinity) was used given the strong correlation between these two variables.

We used PAST software (Hammer et al., 2001).

\section{RESULTS}

\section{Environmental parameters}

All the studied water bodies were relatively shallow (Table 1). Although the depths of these lakes varied, they were deepest in November and fell sharply (halved in DMo, Ust, and $\mathrm{EBe}$ ) in March.

Salinity and conductivity were different among lakes $(\mathrm{H}=18.07 ; \mathrm{p}<0.01$ and $\mathrm{H}=17.51$; $\mathrm{p}<0.01$ respectively), much higher in LTW and Ust. Mean water temperature did not significantly differ among the lakes, although that of LTW was almost 2 to $4{ }^{\circ} \mathrm{C}$ higher than that of the others. Water temperature varied between a minimum of $14.8{ }^{\circ} \mathrm{C}$, measured in September in $\mathrm{EBe}$, and a maximum of $31^{\circ} \mathrm{C}$, registered in January in Ust. Average oxygen concentration was relatively high in all water bodies and did not significantly differ between lakes. Water transparency was different $(\mathrm{H}=15.28 ; \mathrm{p}<$ 0.01 ), since it was greater than $0.7 \mathrm{~m}$ in DMo and LTE and more reduced in the rest of the lakes (Table 1).

The ionic composition of the water was heterogeneous, as EBe was bicarbonated-sodic, DMo and LTE were bicarbonated-calcic, LTW was chlorinated-sulfated-sodic, and Ust was chlorinated-sodic (Table 2). The $\mathrm{F}^{\mathrm{V}}$ values were variable and highest in the larger water bodies (EBe, LTW, and Ust).

A cluster analysis based on the environmental variables and chemical compositions of the water identified two groups of lakes separated by the greatest distance. On the one hand, one group was integrated only by LTW due to its relatively high salinity, ion concentrations, and very low transparency and the second group consisted of lower, although variable, salinity and transparency lakes. In this group, Ust was separated because it has intermediate salinity and transparency, and the narrowest grouping was between DMo and LTE because both had the lowest salinities, the greatest water transparencies, and a shared ionic composition (Figure 2).

\section{Ostracods}

Ten ostracod taxa were registered. The highest richness was recorded in LTE and LTW (6 taxa), although these lakes shared only two species. Conversely, the lowest ostracod richness was recorded in Ust (3 taxa) (Table 3).

Heterocypris similis and Heterocypris incongruens were the dominant species, as they were registered in all lakes and the former was the 
Table 1. Limnological parameters (mean and standard deviation) of the five studied water bodies. *Differed significantly among lakes

\begin{tabular}{lrrrrr}
\hline & \multicolumn{1}{c}{ EBe } & \multicolumn{1}{c}{ DMo } & \multicolumn{1}{c}{ LTE } & LTW & Ust \\
\hline Max. depth (m) & $0.80 \pm 0.17$ & $1.02 \pm 0.29$ & $1.28 \pm 0.15$ & $0.78 \pm 0.21$ & $0.85 \pm 0.20$ \\
Salinity* $(\mathbf{g} / \mathbf{L})$ & $1.50 \pm 0.23$ & $0.47 \pm 0.05$ & $1.14 \pm 0.31$ & $8.02 \pm 1.62$ & $3.72 \pm 0.72$ \\
Coductivity* $(\mathbf{m S} / \mathbf{c m})$ & $1.99 \pm 0.33$ & $0.71 \pm 0.07$ & $1.69 \pm 0.47$ & $10.53 \pm 1.87$ & $5.39 \pm 1.07$ \\
Water temperature $\left({ }^{\circ} \mathbf{C}\right)$ & $20.18 \pm 4.82$ & $21.63 \pm 4.12$ & $22.38 \pm 4.35$ & $24.0 \pm 5.03$ & $22.05 \pm 6.42$ \\
Dissolved oxygen $(\mathbf{m g} / \mathbf{L})$ & $8.58 \pm 0.97$ & $8.65 \pm 0.92$ & $8.48 \pm 0.76$ & $8.10 \pm 0.73$ & $8.58 \pm 0.96$ \\
Transparency* $(\mathbf{m})$ & $0.22 \pm 0.08$ & $0.74 \pm 0.23$ & $0.93 \pm 0.44$ & $0.09 \pm 0.06$ & $0.18 \pm 0.08$ \\
pH & $7.85 \pm 0.44$ & $7.70 \pm 0.45$ & $8.25 \pm 0.51$ & $8.78 \pm 0.43$ & $8.38 \pm 0.39$ \\
\hline
\end{tabular}

Table 2. Ionic water compositions of the ecosystems studied

\begin{tabular}{lrrrrr}
\hline & EBe & DMo & LTE & \multicolumn{1}{c}{ LTW } & Ust \\
\hline $\mathbf{C O}_{3}{ }^{2-}$ & 643.4 & 0 & 321.8 & 1206.6 & 563.1 \\
$\mathbf{H C O}^{-}$ & 1326.6 & 683.7 & 522.8 & 508.2 & 890.4 \\
$\mathbf{C l}^{-}$ & 204.5 & 102.2 & 344.5 & 1874.4 & 954.2 \\
$\mathbf{S O}_{4}{ }^{2-}$ & 70.2 & 5.3 & 3.1 & 1750.6 & 525.2 \\
$\mathbf{C a}^{2+}$ & 114.4 & 140.2 & 248.3 & 108.1 & 120.4 \\
$\mathbf{M g}^{2+}$ & 41.6 & 51.2 & 90.3 & 39.3 & 43.6 \\
$\mathbf{K}^{+}$ & 66.2 & 7.6 & 96.2 & 3060.7 & 71.3 \\
$\mathbf{N a}^{+}$ & 670.2 & 70.5 & 32.5 & 3.35 & 1540.3 \\
$\mathbf{F}^{+}$ & 3.13 & 0.2 & 1.26 & & 3.25 \\
\hline
\end{tabular}

Table 3. Ostracods registered in the five studied lakes and their densities (means and standard deviations), expressed as individuals/100 g of sediment

\begin{tabular}{|c|c|c|c|c|c|}
\hline & EBe & DMo & LTE & LTW & Ust \\
\hline $\begin{array}{l}\text { Heterocypris similis } \\
\text { (Wierzejski, 1967) }\end{array}$ & $140.30 \pm 134.12$ & $30.00 \pm 60.00$ & $543.75 \pm 263.09$ & $233.50 \pm 263.70$ & $290.00 \pm 402.94$ \\
\hline $\begin{array}{l}\text { Heterocypris incongruens } \\
\text { (Ramdohr, 1808) }\end{array}$ & $101.63 \pm 129.89$ & $16.25 \pm 32.50$ & $190.63 \pm 221.59$ & $34.75 \pm 69.50$ & $175.00 \pm 163.25$ \\
\hline Candona sp. & & $9.94 \pm 9.17$ & $12.50 \pm 12.50$ & & \\
\hline $\begin{array}{l}\text { Cypridopsis vidua (O.F. } \\
\text { Müller, 1776) }\end{array}$ & $0.81 \pm 1.61$ & $142.80 \pm 138.16$ & $431.25 \pm 468.43$ & & $1.00 \pm 2.00$ \\
\hline $\begin{array}{l}\text { Chlamydotheca incisa } \\
\text { (Claus, 1893) }\end{array}$ & $1.61 \pm 3.23$ & $89.64 \pm 86.65$ & $65.63 \pm 71.72$ & & \\
\hline $\begin{array}{l}\text { Potamocypris unicaudata } \\
\text { Schäfer, } 1943\end{array}$ & & & $50.00 \pm 70.71$ & & \\
\hline $\begin{array}{l}\text { Amphycipris argentinen- } \\
\text { sis Fontana \& Ballent, } \\
2005\end{array}$ & & & & $6.50 \pm 13.00$ & \\
\hline $\begin{array}{l}\text { Limnocythere rionegroen- } \\
\text { sis Cusminsky \& Whatley, } \\
1996\end{array}$ & & & & $121.75 \pm 172.06$ & \\
\hline $\begin{array}{l}\text { Limnocythere titicaca } \\
\text { Lerner-Seggev, } 1973\end{array}$ & & & & $126.00 \pm 145.49$ & \\
\hline $\begin{array}{l}\text { Limnocythere sp. } \\
\text { No determinated juvenil } \\
\text { specimens }\end{array}$ & & & $12.50 \pm 25.00$ & $6.50 \pm 13.00$ & \\
\hline
\end{tabular}




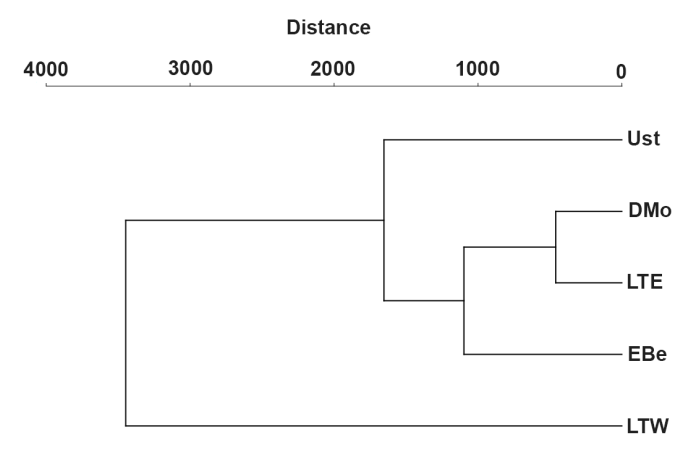

Fig. 2. Grouping of lakes based on the main limnological parameters and ionic compositions of their waters.

most abundant species, exceeding 500 ind./100 g sed. in LTE (Table 3 and Figure 3). They were followed by Cypridopsis vidua and Candona sp., given their lower frequencies of appearance. Other taxa, such as Limnocythere sp., Potamocypris unicaudata, and Amphicypris argentiniensis, were classified as rare species since they presented at low frequencies (registered in only one lake) and low densities (Figure 3).

The cluster analysis revealed two groups of species that showed very low similarity. The Group I, composed by species found only in the highest salinity lake (LTW), was integrated by $A$. argentinensis, Limnocythere titicaca, Limnocythere rionegroensis, and Limnocythere sp. (Figure 4). In group II, two subgroups with low similarity were distinguished: IIa, composed by $C$. vidua, $H$. incongruens and $H$. similis, the species that had a wider distribution, since they were found in almost all environments; and IIb, integrated by Candona sp., Chlamydotheca inci$s a$ and $P$. unicaudata, the species registered only in the low-salinity high-transparency lakes (EBe, DMo, and LTE) (Figure 4).

According to the CCA, the first axis, with an eigenvalue of 0.4989 , and the second axis, with 0.2814 , explained more than $93 \%$ of the variance. The first axis showed a strong correlation with the conductivity (-0.9320) and transparency of the water $(0.77341)$. This analysis showed that the environmental variable that has the greatest influence on the distribution of ostracods is water electrical conductivity (as an indirect measure of salinity) because it showed the same groups that had been formed in the previous cluster analysis. The first group was composed of species that showed a positive correlation with

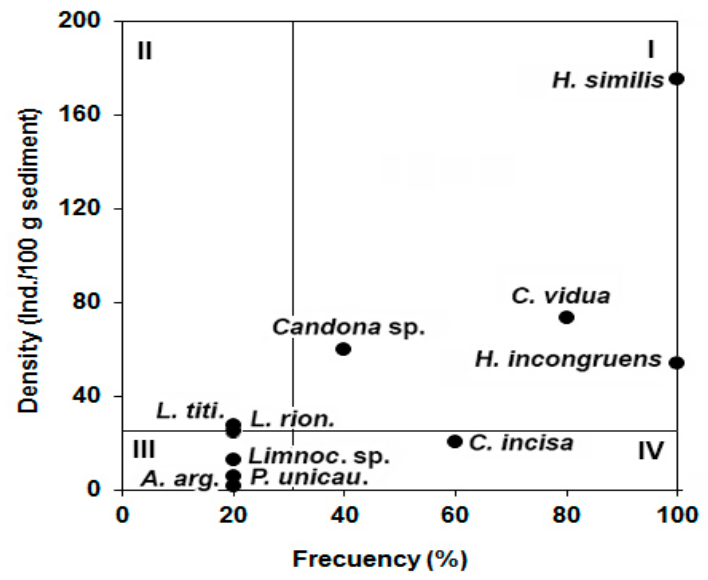

Fig. 3. Results of the Olmstead-Tukey test

conductivity (Group I in the cluster analysis: $A$. argentinensis, $L$. titicaca, $L$. rionegroensis, and Limnocythere sp.). The CCA also revealed that $H$. incongruens and $H$. similis are more tolerant and only slightly influenced by conductivity or other environmental parameters. Therefore, they were found in almost all environments, while $C$. incisa, Candona sp., and $P$. unicaudata (Group IIb in the cluster analysis) had a negative correlation with conductivity but were positively associated with water transparency and oxygen concentration (Figure 5).

Although the mean total ostracods density of LTE (1306 ind./100 g sed.) was almost five times higher than those of EBe and DMo (244 and 288 ind./100 g sed., respectively), this difference was not significant (Figure 6).

Regarding temporal variations in density, we did not detect a homogenous pattern of temporal variation. The densities of LTE, LTW, and DMo were higher in January $(2375,982$, and 670 indiv./100 g sed., respectively). However, the abundance in EBe was higher in March (603 indiv./100 $\mathrm{g}$ sed.) and that in Ust was highest in September (1268 ind./100 g sed.) (Figure 7).

Considering the lake communities separately, in $\mathrm{EBe} H$. similis and $H$. incongruens, were the most abundant species and reached the maximum density in March (313 and 290 indiv./100 g sed. respectively). The other two species, $C$. vidua and $C$. incisa, were found only once, in relatively low densities (3.22 and 6.4 indiv./100 g sed., respectively) (Figure 8).

In DMo, C. vidua was the most abundant species and reached its maximum density in November (330 indiv./100 g sed.). Was followed by C. incisa, wich was more abundant in September 


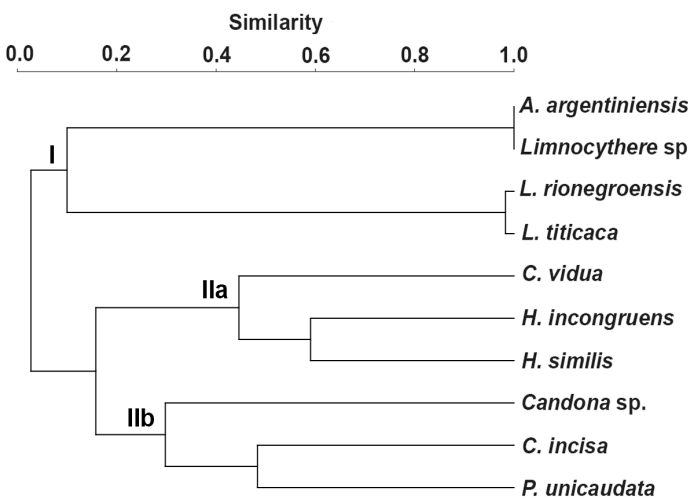

Fig. 4. Groupings of the ostracod taxa registered in the five studied lakes

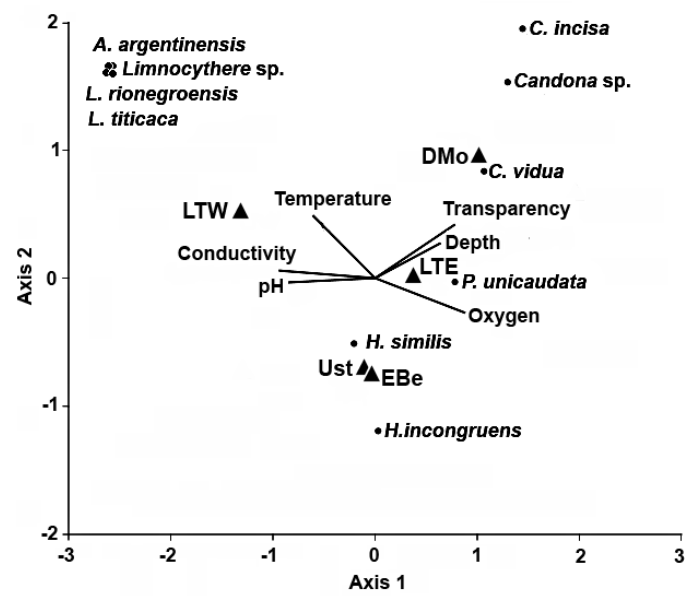

Fig. 5. Results of the canonical correspondence analysis

(185 indiv./100 g sed.). Heterocypris similis and $H$. incongruens were found only in January, albeit with relatively high densities (120 and 65 indiv./100 g sed., respectively) (Figure 8).

In LTE, $H$. similis and $C$. vidua were the most abundant species and reaches their maximum density in January (812.5 and 925 indiv./100 g sed., respectively), followed by $H$. incongruens which reach 412.5 indiv. $/ 100 \mathrm{~g}$ sed., also in January respectively) (Figure 8).

In LTW, $H$. similis was the most abundant species, with a maximum density in September (604 indiv./100 g sed.), followed by L. rionegroensis and L. titicaca, which showed their maximum density in January (365 and 252 indiv./100 g sed. respectively). The rest of the species were found only once with much lower densities (Figure 8).

In Ust, $H$. similis was the most abundant species followed by $H$. incongruens. They registered their maximum densities in September $(872$

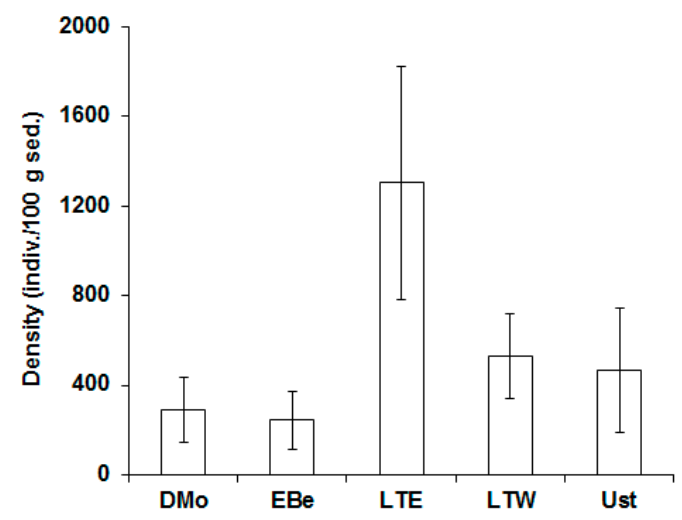

Fig. 6. Comparison of the total average densities recorded in the five studied bodies of water. The bars indicate standard deviations.

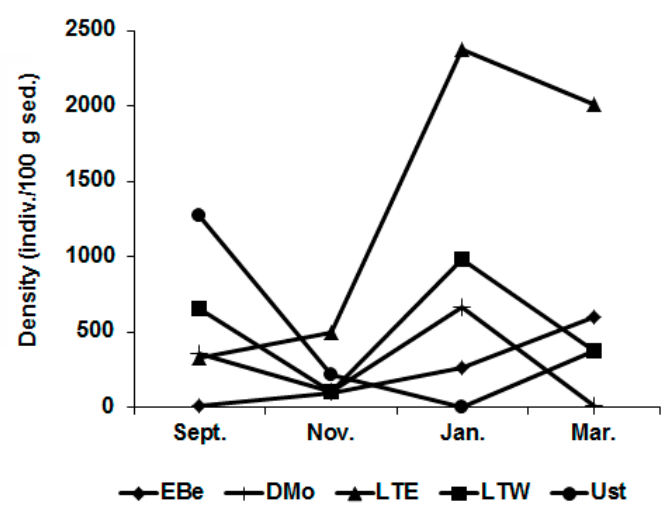

Fig. 7. Temporal variations in the densities of the ostracod taxa recorded in the five studied lakes.

indiv./100 g sed.) and November (180 indiv./100 $\mathrm{g}$ sed.). Cypridopsis vidua was found only in September at a low density (4 indiv./100 g sed.). No ostracods were found in January (Figure 8).

\section{DISCUSSION}

Despite the short distance among them, the set of ecosystems studied was highly heterogeneous, and the characteristics were relatively different in terms of size, water transparency, and salinity. Although two ecosystems (Ust and LTW) could be considered saline lakes (Hammer, 1986), with a predominance of $\mathrm{Cl}^{-}$, the analysis showed that LTW was relatively different because its salinity was much higher, which was reflected by the association of the species. On the other hand, EBe, DMo, and LTE are subsaline lakes (Hammer, 1986) with a predominance of bicarbonate, but the first differs slightly because 

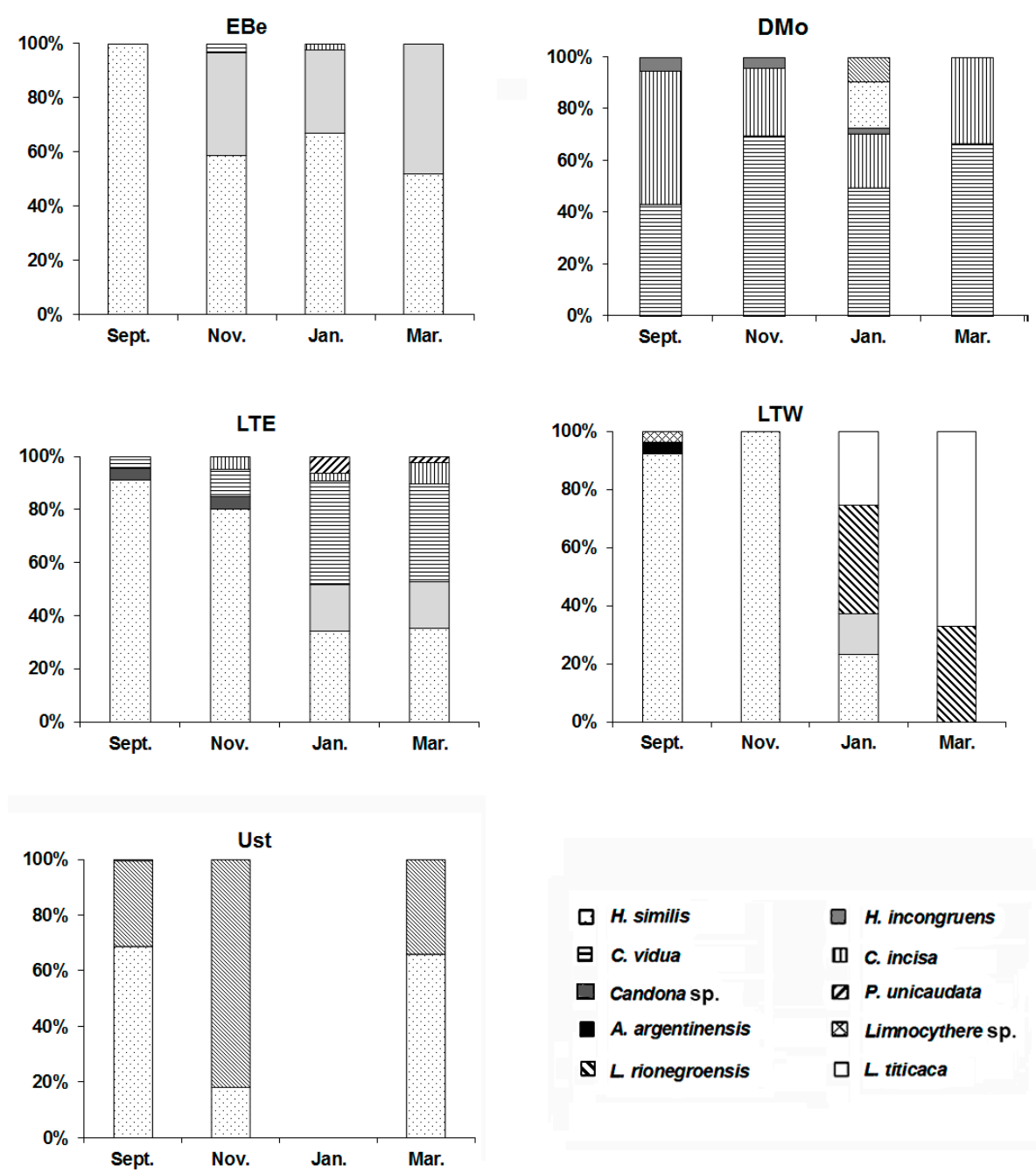

Fig. 8. Temporal variations in the densities (\%) of the ostracod taxa recorded in the five studied lakes

it is more extensive and its transparency is much lower. The greater transparency that characterizes DMo and LTE is related to a greater vegetation cover that inhibits the growth of phytoplankton and decreases the removal of sediments by the wind (Echaniz \& Vignatti, 2019).

Considering that the sampled lakes are located in a relatively small area, the total richness of ostracods was relatively high, probably due to the physical-chemical differences between the ecosystems, especially in conductivity (as an indirect measure of salinity). The richness found in this study was similar to that recorded by D’Ambrosio et al. (2017) (eleven taxa) in a heterogeneous set of aquatic ecosystems (lentic and lotic) in the Llancanelo Lake basin (Mendoza Province). The richness of ostracods in Northern
Pampa was relatively high compared to that found in a transect of more than $700 \mathrm{~km}$ covering the regions of the Espinal (La Pampa Province), the Patagonian Steppe (Río Negro Province), and the Andean forest in Northern Patagonia (Neuquén and Río Negro Provinces) (Coviaga et al., 2018) or than that recorded in temporary fishless ponds near San Carlos de Bariloche (Río Negro Province) (Coviaga et al., 2015). However, the species number was lower compared to the twenty taxa registered by Laprida (2006) in the Depressed Pampa plain (Buenos Aires province), an extensive region with a high abundance of aquatic ecosystems.

The ostracod fauna found in this study was similar to that registered in temporary and permanent water bodies in Buenos Aires 
Province, characterized by $H$. similis, $H$. incongruens, Candona sp., C. vidua, C. incisa, and Limnocythere sp. (Laprida, 2006); this was expected because both the aquatic ecosystems studied by Laprida (2006) and those in the northeast of La Pampa, are located in the Pampa ecoregion (Morello et al., 2012). On the other hand, the Pampean sampled lakes share only two taxa $(H$. incongruens and $C$. vidua) with the fauna found in the Llancanelo Lake basin (D'Ambrosio et al., 2017), located in the Patagonian Steppe ecoregion (Payunia subregion) (Morello et al., 2012). Additionally, the Pampean studied lakes share five taxa (C. incisa, C. vidua, P. unicaudata, $H$. incongruens, and $A$. argentiniensis) with those found by Coviaga et al. (2018) in the aforementioned transect of Northern Patagonia.

The importance of salinity as a structuring factor for communities (Ruiz et al., 2013; Martínez-García et al., 2015; Coviaga et al., 2015) shown by the CCA was also verified in the present study. A group of species composed of $A$. argentinensis, $L$. rionegroensis, $L$. titicaca, and Limnocythere sp. showed preference for saline lakes because they were found only in the saline LTW. Conversely, species such as C. incisa, Candona sp., and P. unicaudata were restricted to very low salinity ecosystems, while $H$. incongruens and $H$. similis thrived over a wider range of salinity levels.

Considering the clustering of taxa registered in this study, $H$. similis and $H$. incongruens, previously found in La Pampa (Kihn \& Pall, 2013; Kihn et al., 2017), can tolerate a wide range of salinity and are widely distributed in South America (Ramírez, 1967; Martens \& Behen, 1994; César et al., 2001; Laprida, 2006). Heterocypris incongruens, is a cosmopolitan species (Külköylüoğlu, 2013; Fernández et al., 2016) frequently found in Buenos Aires Province (Ramírez, 1967; Laprida, 2006) and Patagonia (Schwalb et al., 2002; Cusminsky et al., 2005; 2011) that could be used as an indicator of water pollution (Van der Meeren et al., 2010). The dominance of $H$. incongruens in Pampean lakes coincides with that found by $\mathrm{D}^{\prime}$ Ambrosio et al. (2017) in Llancanelo and by Coviaga et al. (2018) in Northern Patagonia.

Among the taxa found in the lowest-salinity lakes, C. incisa is widely distributed in subsaline, shallow, vegetated, and chlorinated sodium lakes of South America and Argentina (Ramírez, 1967; Martens \& Behen, 1994; César et al., 2001; Laprida, 2006; Díaz \& Lopretto, 2011; Kihn et al., 2017). These conditions were found in DMo, and LTE, which have coverage of Schoenoplectus californicus in the Pampean lakes bicarbonate predominates.

Together with C. incisa, C. vidua was found. Cypridopsis vidua is a cosmopolitan species (Külköylüoğlu, 2013; D’Ambrosio, 2014) registered in Buenos Aires Province (Laprida, 2006; Liberto et al., 2012) and Mendoza Province (D’Ambrosio et al., 2017). Although Roca et al. (1993) mentioned that C. vidua prefers periphyton growing on Chara fragilis, in La Pampa it was recorded in the benthos, even in Ust, a lake that lacks aquatic vegetation. In Pampean lakes, C. vidua reach relatively high densities (only surpassed by those of $H$. similis), which is consistent with that found in other studies (FernandesMartins et al., 2010; Martínez-García, 2015).

Considering the species found in the lakes with the highest salinity, although it has been indicated that species of the genus Amphicypris mostly inhabit freshwater lakes (Fontana \& Ballent, 2005), A. argentinensis was found in La Pampa at a salinity of $9.32 \mathrm{~g} / \mathrm{L}$.

Limnocythere rionegroensis, present in recent environments of Patagonia is an indicator of environments with high saline concentrations (Cusminsky et al., 2005) resulting from high evaporation and chemical compositions rich in chlorides or sulfates (Ramón Mercau et al., 2012, what can explain its presence only in LTW. Limnocythere titicaca, which has also been registered in Runtuyoc Lake (northwest of Argentina) (D’Ambrosio et al., 2020), prefers permanent lakes (Palacios-Fest et al., 2016). However, in La Pampa, this species was registered in LTW, which can dry up ocasionally.

The total mean density of the lakes was not different despite the fact that the density recorded for LTE was higher. This may be due to the high variability in the density because there was a time when no ostracods were recorded, such as in Ust in January or on occasions when the density exceeded 2000 ind./100 g sed. as in LTE during January and March. Although in three lakes the density was higher in January, a seasonal pattern of variation was not found.

La Pampa province is a transition zone characterized by a rainfall gradient from a mean of $800 \mathrm{~mm} /$ year in the northeast to $300 \mathrm{~mm} /$ year towards the southwest (Morello et al., 2012). This means that different ecoregions are represented in its territory from the fertile Pampa Plains in the wetter northeast to the arid Patagonian steppe in the southwest (Morello et al., 2012). These conditions affect the characteristics of their wa- 
ter bodies, which show considerable heterogeneity, sometimes in small geographic areas (Echaniz \& Vignatti, 2019), such as those included in this study.

This study shows the presence in La Pampa of ostracods previously registered in northwestern Argentina as L. titicaca, others frequent in the center of the country $(H$. similis) but not found in northern Patagonia (Coviaga et al., 2018) or south of Mendoza Province (D’Ambrosio et al. (2017) and, conversely, the presence in pampean lakes of $L$. rionegroensis, typical of Patagonia (Cusminsky et al., 2005, Cusminsky et al., 2011, Ramón Mercau et al., 2012). This co-occurrence in addition to its geographical location and climatic characteristics could indicate that the lakes of La Pampa are in a transition zone among the faunas of the north, center, and south of Argentina.

\section{ACKNOWLEDGMENTS}

We thank the owners of the establishments in which the lakes are located and the anonymous reviewers whose comments improved this contribution.

\section{REFERENCES}

APHA. 1992. Standard Methods for the Examination of Water and Wastewater. 18th edition. American Public Health Association (APHA), American Water Works Association (AWWA) and Water Pollution Control Federation (WPCF). Washington, DC.

Ballent, S.C. \& A.R. Díaz. 2012. Contribution to the taxonomy, distribution and paleoecology of the early representatives of Penthesilenula Rossetti \& Martens, 1998 (Crustacea, Ostracoda, Darwinulidae) from Argentina, with the description of a new species. Hydrobiologia 688 (1): 125-138.

Barros, V., J. Boninsegna, I. Camilloni, M. Chidiak, G. Magrín \& M. Rusticucci. 2014. Climate change in Argentina: trends, projections, impacts and adaptation.WIREs Clim Change 6:151-169.

Bertels, A. \& D.E. Martínez. 1990. Quaternary ostracodes of continental and transitional littoral-shallow marine environments. Courier Forschchungs Institut Senckenberg 123: 141-160.

Cárdenas, J., A. Díaz, D. Álvarez \& R. Urrutia. 2015. Nuevos registros de ostrácodos no-marinos (Crustacea, Ostracoda) en Patagonia Occidental, Chile. Gayana 79(1): 106-109.

César, I.I., L.C. Armendáriz \& M.C. Damborenea. 2001. Ostrácodos (Crustacea) de la Isla Martín García, Río de la Plata, Argentina. Natura Neotropicalis 32(2): 147-151.

Coviaga, C., G. Cusminsky, N. Baccalá \& A.P. Pérez. 2015. Dynamics of ostracod populations from shallow lakes of Patagonia: life history insights. Jour- nal of Natural History 49(17.18): 1023-1045.

Coviaga, C., G. Cusminsky \& P. Pérez. 2018. Ecology of freshwater ostracods from Northern Patagonia and their potential application in paleo-environmental reconstructions. Hydrobiologia (816): 3-20.

Cusminsky, G.C. \& R. Whatley. 1996. Quaternary nonmarine ostracods from lake beds in northern Patagonia. Revista española de paleontología 11(2): 143-154.

Cusminsky, G.C., P.A. Pérez, A. Schwalb \& R.C. Whatley. 2005. Recent lacustrine ostracods from Patagonia, Argentina. Revista Española de Micropaleontología 37: 431-450.

Cusminsky, G., A. Schwalb, A.P. Pérez, D. Pineda, F. Viehberg, R. Whatley, V. Markgraf, A. Gilli, D. Ariztegui \& F.S. Anselmetti. 2011. Late Quaternary environmental changes in Patagonia as inferred from lacustrine fossil and extant ostracods. Biological Journal of the Linnean Society 103: 397-408.

D’Ambrosio, S. 2014. Reconstrucción paleolimnológica de la Laguna Llancanelo (Mendoza, Argentina) a través del estudio de ostrácodos del Cuaternario. Facultad de Ciencias Naturales y Museo, Universidad Nacional de La Plata. Tesis Doctoral, 181 pp.

D’Ambrosio, D.S., M.C. Claps \& A. García. 2016. Zooplankton diversity of a protected and vulnerable wetland system in southern South America (Llancanelo area, Argentina). International Aquatic Research 8: 65-80.

D’ Ambrosio, D., A. García, A. Díaz, A. Chivas \& M. Claps. 2017. Distribution of ostracods in westcentral Argentina related to host-water chemistry and climate: implications for paleolimnology. Journal of Paleolimnology 58: 101-117.

D’ Ambrosio, S., L. Rojo \& S. Fontana. 2020. Quaternary non-marine ostracods of Runtuyoc lake, northern Argentina: New taxonomic descriptions and the implication for Holocene paleoenvironment. Journal of South American Earth Sciences 98, article $\mathrm{n}^{\circ} 102451$.

Díaz, A. \& E. Lopretto. 2011. The genus Chlamydotheca Saussure (Crustacea: Ostracoda) in northeastern Argentina. Nauplius 19(2): 97-107.

Echaniz, S., A. Vignatti, S. José de Paggi, J. Paggi \& A. Pilati. 2006. Zooplankton seasonal abundance of south american saline shallow lakes. International Review of Hydrobiology 91: 86-100.

Echaniz, S., A. Vignatti, G. Cabrera \& S. José de Paggi. 2012. Zooplankton richness, abundance and biomass of two hypertrophic shallow lakes with different salinity. Biota Neotropica 12 (2): 37-44.

Echaniz, S. \& A. Vignatti. 2017. The zooplankton of the shallow lakes of the semi-arid region of southern South America. Annales de Limnologie - International Journal of Limnology 53: 345-360.

Echaniz, S. \& A. Vignatti. 2019. Limnology of shallow lakes of the semi-arid Central Pampa of Argentina. Acta Limnologica Brasiliensia vol. 31, e11.

Echeverría Galindo, P., L. Pérez, A. Correa-Metrio, C. Avendaño, B. Moguel, M. Brenner, S. Cohuo, L. Macario, M. Caballero \& A. Schwalb. 2019. Tropical freshwater ostracodes as environmental indica- 
tors across an altitude gradient in Guatemala and Mexico. Revista de Biología Tropical 67(4): 10371058.

Fernandes Martins, M., T. Namiotko, M. Cabral, F. Fatela \& M. Boavida. 2010. Contribution to the knowledge of the freshwater Ostracoda fauna in continental Portugal, with an updated checklist of Recent and Quaternary species. Journal of Limno$\log y$ 69(1): 160-173.

Fernandez, R., S. Nandini, S.S.S. Sarma \& M.E. Castellanos-Páez. 2016. Demographic Responses of Heterocypris Incongruens (Ostracoda) Related to Stress Factors of Competition, Predation and Food. Journal of Limnology 75 (1s): 31-38.

Ferrero, L. 2006. Micropaleontología y Paleoecología del Cuaternario del sudeste de la provincia de Buenos Aires. Facultad de Ciencias Exactas y Naturales, Universidad Nacional de Mar del Plata. Tesis Doctoral, $373 \mathrm{pp}$.

Fontana, S.L. \& S. Ballent. 2005. A new giant cypridid ostracod (Crustacea) from southern Buenos Aires Province, Argentina. Hydrobiologia 533: 187-197.

Hammer, Ø, D. A. Harper \& P. D. Ryan. 2001. PAST: Paleontological Statistics Software Package for Education and Data Analysis. Palaeontologia Electronica, 4 (1): 1-9.

Hammer, U. 1986. Saline Lake Ecosystems of the World. Dr. W. Junk Publishers, Dordrecht, 616 pp.

Karanovic, I. 2012. Recent freshwater ostracods of the world: Crustacea, Ostracoda, Podocopida. Ed. Springer, $610 \mathrm{pp}$.

Kihn, R. \& J.L. Pall. 2013. Diversity of the present ostracofauna in lagoons of the central region of the Republic Argentina. Munis Entomology \& Zoology 8 (1): 273-277.

Kihn, R., F. Crespo \& J.L. Pall. 2017. Ostrácodos de lagos someros de la región central de Argentina: implicaciones paleolimnológicas. Revista Brasileira de Paleontologia 20 (3): 373-382.

Külköylüoğlu, O. 2013. Diversity, distribution and ecology of nonmarine Ostracoda (Crustacea) in Turkey: Application of pseudorichness and cosmoecious species concepts. Recent Research Development in Ecology 4: 1-18.

Laprida C. 2006. Ostrácodos recientes de la llanura pampeana, Buenos Aires, Argentina: ecología e implicancias paleolimnológicas. Ameghiniana 43: 181-204.

Laprida, C., A. Díaz \& N. Ratto. 2006. Ostracods (Crustacea) from thermal waters, southern Altiplano, Argentina. Micropaleontology 52 (2): 177-188.

Liberto, R., J. Mesquita \& I. César. 2012. Dynamics of pleustonic ostracod populations in small ponds on the Island of Martín García (Rio de la Plata, Argentina). Hydrobiologia 688: 47-61.

Martens, K \& F. Behen. 1994. A checklist of the recent non-marine ostracods (Crustacea, Ostracoda) from the inland waters of South America and adjacent islands. Travaux Scientifiques du Musee National d'Histoire Naturelle de Luxembourg 22: 1-84.

Martens, K. \& D. J. Horne. 2016. Collecting and processing living, non-marine ostracods. Journal of crustacean biology 36(6): 849-854.

Martínez-García, B., O. Suárez-Hernando, J. Mendıcoa \& X. Murelaga, 2015. Living ostracod species from permanent and semi-permanent ponds of Bardenas Reales de Navarra (Northern Spain) with remarks on their ecological requirements. Ameghiniana 52: 598-612.

Meisch, C. 2000. Freshwater Ostracoda of western and central Europe. In: Schwoerbel, J. \& P. Zwick (Eds.), Süßwasser fauna von Mitteleuropa 8(3). Spektrum Akademischer Verlag, Heidelberg. Berlin, $522 \mathrm{pp}$.

Mezquita, F., H. Griffiths, S. Sanz, J. Soria \& A. Piñón. 1999. Ecology and distribution of ostracods associated with flowing waters in the eastern Iberian Peninsula. Journal of Crustacean Biology 19(2): 344-354.

Moore, R. 1961. Treatise on Invertebrate Paleontology. Part Q. Arthropoda 3: Crustacea, Ostracoda. Geological Society of America, New York, $442 \mathrm{pp}$.

Morello J., S. Matteucci, A. Rodríguez \& M. Silva. 2012. Ecorregiones y complejos ecosistémicos argentinos. Orientación Gráfica Editores, Buenos Aires, 800 pp.

Palacios-Fest, M., G. Cusminsky \& M. Mc Glue. 2016. Late Quaternary lacustrine ostracods (Ostracoda, Crustacea) and charophytes (Charophyta, Charales) from the Puna Plateau, Argentina. Journal of Micropalaeontology 35: 66-78.

Perçin Paçal, F. 2011. The ecology of the Ostracoda (Crustacea) species obtained from the coasts of Iskenderun Bay (Eastern Mediterranean Sea). J. Black Sea/Mediterranean Environment Vol. 17(2): 127-144.

Pérez, L., J. Lorenschat, R. Bugja, M. Brenner, B. Scharf \& A. Schwalb. 2010. Distribution, diversity and ecology of modern freshwater ostracodes (Crustacea), and hydrochemical characteristics of Lago Petén Itzá, Guatemala. Journal of Limnology 69(1): 146-159.

Pieri, V., K. Martens, F. Stoch \& G. Rossetti. 2009. Distribution and ecology of non-marine ostracods (Crustacea, Ostracoda) from Friuli Venezia Giulia (NE Italy). Journal of Limnology 68(1): 1-15.

Pinto, R., C. Rocha \& K. Martens. 2005. On new terrestrial ostracods (Crustacea, Ostracoda) from Brazil, primarily from São Paulo State. Zoological Journal of the Linnean Society 145: 145-173.

Ramírez, F. 1967. Ostrácodos de lagunas de la Provincia de Buenos Aires. Revista del Museo de la Plata (Zool.73): 5-54.

Ramón Mercau, J., C. Laprida, J. Massaferro, M. Rogora, G. Tartari \& N.I. Maidana. 2012. Patagonian ostracods as indicators of climate-related hydrological variables: implications for paleoenvironmental reconstructions in Southern South America. Hydrobiologia 694: 235-251.

Roca, J., A. Baltanas \& F. Uiblein. 1993. Adaptive responses in Cypridopsis vidua (Crustacea: Ostracoda) to food and shelter offered by a macrophyte (Chara fragilis). Hydrobiologia 262 (2): 127-131.

Ruiz, F., M. Abad, A.M. Bodergat, P. Carbonel, J. Ro- 
dríguez-Lázaro, M.L. González-Regalado, A. Toscano, E.X. García \& J. Prenda. 2013. Freshwater ostracods as environmental tracers. International Journal of Environmental Science and Technology 10: 1115-1128.

Schwalb, A., S. Burns, G. Cusminsky, K. Kelts \& V. Margraf. 2002. Assemblage diversity and isotopic signals of modern ostracodes and host waters from Patagonia, Argentina. Paleogeography. Paleoclimatology, Palaeoecology 187: 323-339.

Shornikov, E. 1980. Ostracodes in terrestrial biotopes. Zoologicheskii Zhurnal 59: 1309-1319.

Sokal, R. \& F. Rohlf. 1995. Biometría. Principios y métodos estadísticos en la investigación biológica. Ed.
Blume, Barcelona, 832 pp.

Ter Braak, C. \& F. Verdonshot. 1995. Canonical correspondence analysis and related multivariate methods in Aquatic Ecology. Aquatic Sciences 57: 255-286.

Van der Meeren, T., J.E. Almendinger, E. Ito \& K. Martens. 2010. The ecology of ostracodes (Ostracoda, Crustacea) in western Mongolia. Hydrobiologia 641: 253-273.

Vignatti, A., S. Echaniz \& M. Martín. 2007. El zooplancton de lagos someros de diferente salinidad y estado trófico en la región semiárida pampeana ( $\mathrm{La}$ Pampa, Argentina). Gayana 71(1): 38-48.

Doi: 10.22179/REVMACN.22.679

Recibido: 16.III.2020

Aceptado: 18-IX-2020 